\title{
Identification of Sweet Cherry Cultivars (Prunus avium L.) and Analysis of Their Genetic Relationship Using Microsatellite DNA Fingerprinting
}

\author{
M. Turet-Sayar ${ }^{1}$, A. Turkec ${ }^{2} \&$ T. Demir ${ }^{3}$ \\ ${ }^{1}$ Department of Molecular Biology and Genetics, University of Bogazici, Bebek, Istanbul, Turkey \\ ${ }^{2}$ Mustafa Kemalpasa Vocational School, University of Uludag, Bursa, Turkey \\ ${ }^{3}$ Geyve Vocational School, University of Sakarya, Turkey \\ Correspondence: A. Turkec, Mustafa Kemalpasa Vocational School, University of Bursa, 16500 Bursa, Turkey. \\ Tel: 90-224-613-3102. E-mail: aturkec@uludag.edu.tr
}

Received: April 26, 2012 Accepted: May 10, 2012 Online Published: July 11, 2012

doi:10.5539/jas.v4n8p134 URL: http://dx.doi.org/10.5539/jas.v4n8p134

\begin{abstract}
Genetic diversity of seven Turkish sweet cherry cultivars and eight commonly grown introduced cultivars were assessed using 23 microsatellite (SSR) markers. Among the markers, nine primers produced polymorphic patterns resulting in 56 informative alleles. The mean number of alleles per locus was 5.4 while the mean similarity over the nine polymorphic loci averaged 0.463 . UPGMA cluster analysis of the data separated cultivars and accessions into two main groups. The results demonstrated that Turkish sweet cherry cultivars have less genetic variation and more closely related to each other. These cultivars contained both Turkish germplasm as well as European and American germplasm in their pedigree. In the present study, same SSR primers were also used to clarify the genetic identity of registered cultivar, 0900Ziraat, which is highly grown in different nurseries all over Turkey but confusingly referred to under different name by local growers due to certain pomological and morphological differences observed among the trees. SSR analysis of seventeen individual tree samples from eight nurseries at different locations, have revealed no genetic variation among samples. The phenotypic variations among the trees were the most probably due to local adaptations to different locations and variations in rootstocks that were used in nurseries rather than the genetic variations among the 0900Ziraat cultivars.
\end{abstract}

Keywords: cultivar identification, SSR, microsatellites, Prunus avium, sweet cherry

\section{Introduction}

The sweet cherry was originated in the mountains of north easthern part of Turkey, near the Black Sea region, from where it has spread in Roman times (Zohary \& Hopf, 2000). Turkey is one of the leading countries in production and export of sweet cherries (Faostat, 2011). Suitable climatic conditions and excellent export market demand have resulted in continuous increase in annual production. Several different varieties of sweet cherry are grown at different altitudes and latitudes in Turkey (Kaska et al., 1998). Superior cultivars were propagated by grafting of cultivars using narrow genetic background (Kacar, 2001). Occasionally, new cultivars were also emerged from seeds (Heinze, 1999). The combination of different cultivars planted at different elevations result in a large harvest window. In Turkey, traditional cherry cultivation mainly involves maintenance of small orchards by different owners; this creates confusion in naming cultivars to their trueness to type. Rather than the use of registered names of the cultivars, sometimes the same cultivar is given different names or different cultivars are given the same name indicative of the fruit shape or local growth area by orchard owners (Kacar, 2001; Kacar et al., 2005). The identification of the sweet cherry cultivars has long been performed by pomological, and morphological traits which were easily influenced by environmental and agronomical factors (Struss et al., 2001). Today, identification of economically valuable sweet cheery genotypes relay on fast and reliable genetic approaches using molecular techniques. The studies on genetic diversity and phylogenetic analysis on cherries frequently used chloroplast and nuclear markers due to their different mode of inheritance and higher mutation rates. PCR based cpDNA-markers, (Mohanty et al., 2001; Turkec et al., 2006) and SSR markers have been common approaches for DNA fingerprinting in most plant species including fruit trees (Wunsch \& Hormaza, 2004; Lacis et al., 2010) due to their high polymorphism, codominancy and reproducibility. In Prunus species, most of the available SSR sequences have been developed from peach (Cipriani et al., 1999; Testolin et al., 2000; Dirlewanger et al., 2002), sweet cherry (Sosinski et al., 2000; Dirlewanger et al., 2002; Pederson, 2006) and sour cherry (Downey \& Lezzoni 2000; Cantini et al., 2001; Lacis 
et al., 2009) species which were widely used over the last 10 years to assess the genetic diversity among genotypes (Kacar et al., 2005; Guarino et al., 2010) as well as rootstocks (Turkoglu et al, 2010; Demir et al., 2011) The objectives of the present study were (i) to analyze the genetic diversity of seven Turkish sweet cheery cultivars/accessions and eight introduced foreign cultivars grown in Turkey using SSR markers developed for peach, sweet cherry and sour cherry species, and (ii) to clarify the genetic identity of a registered cultivar, "0900Ziraat", which was observed to display different phenotypic characteristics such as fruit color, fruit shape and leave structures and thus referred under different names in nurseries in different parts of Turkey.

\section{Material and Methods}

\subsection{Plant Material}

In the present study, two sets of plant material were used. The first set consisted of fifteen Prunus avium L. genotypes which included eight foreign sweet cherry cultivars (Lapins, Sweet Heart, Northwunder, Bing, Canada Giant, Regina, Stella, and Ferrovia) introduced in Turkey, one registered "0900Ziraat" cultivar, four accessions (YLV900H, A900, 0904 and 0905), and two local cultivars (Malatyadalbasti and Kazancioglu). The second sets of plant material included sixteen individual samples of the registered cultivar 0900Ziraat, which were collected from different nurseries across Turkey (Lapseki, Canakkale; Kemalpasa, Izmir; Salihli, Izmir; Asagiyakacik, Nazilli; Honaz, Denizli; Golpazari, Bilecik; Uluborlu, Isparta; Aksehir, Konya; Golcayir, Afyon; Sultandag, Afyon and Yesilciflik, Afyon). Exact locations of the sampled trees in each nurseries were recorded to trace back any inconsistencies.

\subsection{DNA Isolation}

Young leaves were collected from a single tree for each genotype and immediately frozen in liquid nitrogen and stored at $-80^{\circ} \mathrm{C}$ until used for DNA isolation. Total genomic DNA was extracted using the CTAB method (Doyle \& Doyle, 1987). Frozen buds and leaves were grinded in liquid nitrogen, containing autoclaved aquarium sand by using mortar and pestle. Tissue homogenates were suspended in $800 \mathrm{ml}$ extraction buffer $(0.25 \%$ SDS, $400 \mathrm{mM}$ Tris- $\mathrm{HCl} \mathrm{pH}: 8.0,60 \mathrm{mM}$ EDTA, $150 \mathrm{mM} \mathrm{NaCl}, 10 \mathrm{mM} \beta$-mercaptoethanol and $1.25 \mathrm{M}$ sodium acetate) and incubated at $65^{\circ} \mathrm{C}$ for $30 \mathrm{~min}$. Following the incubation, equal volume of phenol:chloroform:isoamylalcohol (25:24:1) solution was added before centrifugation at 14000rpm for $20 \mathrm{~min}$. Genomic DNA from the aqueous phase was precipitated using $450 \mu \mathrm{l}$ ice-cold isopropanol by centrifugation at $14000 \mathrm{rpm}$ for $20 \mathrm{~min}$. The pellet was gently washed with $1 \mathrm{ml}$ absolute ethanol and $1 \mathrm{ml} 70 \%$ ethanol respectively before the pellets were air dried. Genomic DNA was dissolved in 50 $\mu$ TE buffer (10mM Tris-HCl pH:8, 1mM EDTA). Dissolved DNA was treated with RNase $\left(10 \mathrm{mg} \mathrm{ml}^{-1}\right.$, Promega) according to the suppliers manual. Concentration and quality of DNA were determined by spectrophotometry and $1 \%$ agarose gel electrophoresis respectively.

\subsection{PCR Amplification and SSR Analysis}

PCR reactions were performed in a total volume of $15 \mu$ l containing $25 \mathrm{ng}$ of template DNA, $0.2 \mu \mathrm{M}$ of each primer (Table 1), $0.6 \mathrm{U}$ of Taq DNA polymerase (Promega), $200 \mu \mathrm{M}$ of dNTPs and $1 \mathrm{X}$ reaction buffer (20 mM Tris-HCl, $50 \mathrm{mM} \mathrm{KCl}, 2 \mathrm{mM}$ of $\mathrm{MgCl}_{2}$ ). A total of 23 previously developed SSR primers were used as listed in Table 1. The PCR cycle was carried out in a GeneAmp 9600 thermal cycler (Perkin-Elmer Cetus) by initial denaturation at $94{ }^{\circ} \mathrm{C}$ for $3 \mathrm{~min}$. followed by 32 cycles of $94^{\circ} \mathrm{C} 30 \mathrm{~s}, 55^{\circ} \mathrm{C} 30$ s (annealing temperatures were optimized for each primer pairs), $70{ }^{\circ} \mathrm{C} 45 \mathrm{~s}$, and followed by a final extension at $72{ }^{\circ} \mathrm{C}$ for $10 \mathrm{~min}$. The PCR products were run on a $6 \%$ polyacrylamide gel (BioRad Sequi-Gen ${ }^{\circledR}$ sequencer) containing $7.5 \mathrm{M}$ of urea in $0.5 \mathrm{X}$ TBE buffer ( $90 \mathrm{mM}$ Tris, $90 \mathrm{mM}$ boric acid, $2 \mathrm{mM}$ EDTA) for $2 \mathrm{~h}$ at $80 \mathrm{~W}$. The visualization of the DNA bands were performed by silver-staining according to the protocol described by Cho et al. (1996). The amplified fragments were sized using 100-bp DNA ladder (Fermentas) and scored visually. SSR marker analyses for each locus were repeated twice to check the consistency of the results obtained.

Table 1. SSR primers used in this study

\begin{tabular}{lll}
\hline SSR primers & Origin & References \\
\hline UDP-001, UDP-003, UDP-005, UDP-401, & Peach genomic DNA & Cipriani et al. (1999) \\
UDP-403, UDP-405,UDP-406, UDP-409, UDP-410 & & Testolin et al. ( 2000) \\
BPPCT-34, BPPCT-38, BPPCT-39, BPPCT-40 & Peach genomic DNA & Dirlewanger et al. (2002) \\
Pchgms3 & Peach genomic DNA & Sosinski et al. (2000) \\
PS12A02, PS08E08 & Sweet cherry genomic DNA & Sosinski et al. (2000) \\
PMS2, PMS3, PMS30, PMS40, PMS49 & Sweet cherry genomic DNA & Struss et al. (2002) \\
PceGA25, PceGA59 & Sour cherry genomic DNA & Lezzoni et al. (1990) \\
\hline
\end{tabular}




\subsection{Data Analysis}

SSR fragments obtained for each primer pairs were scored as present (1) or absent (0) for each genotype. Dendrogram was produced by cluster analysis based on the Nei and Li similarity index using UPGMA (Nei \& Li, 1979) with NTSYS-pc software, version 2.02i (Exeter Software, Stauket, New York, NY, USA).

\section{Results}

\subsection{SSR Analysis}

Twenty three SSR markers have been tested on 31 genotypes of Prunus avium. Fourteen of the SSR primer pairs used was previously developed for peach, seven were developed for sweet cherries and two were developed for sour cherries (Table 1). Of the 23 primer pairs used 18 (78\%) generated amplification products. However, for the first set of plant material, five of the primer pairs have been discarded, due to the fact that either the differences among band sizes were too small to be accurately scored ( UDP96-001 and UDP96-005) or complex (BPPCT-038, BPPCT-039) and inconsistent (UDP96-003) in band patterns. Four of the primer pairs were monomorphic (Pchgms 3, UDP97-401, UDP97-405 and UDP98-409) for all plant samples of the first set. Nine of the primers (50\%) (UDP97-403, BPPCT-034, BPPTCT-40, PS12A02, PMS2, PMS3, PMS40, PceGA25 and PceGA59) were created reproducible and clear polymorphic bands for total 56 loci (Table 2). The average of 6.3 alleles per locus was observed and the lowest alleles per locus were obtained by PMS2 and PceGA59, whereas the highest alleles were obtained by PS12A02. Although most of the observed band sizes were in agreement with the expected size ranges (Table 2), some of the primers however created additional bands with higher sizes in comparison to expected band size ranges. For the second set of plant material, all eighteen of the primer pairs were tested on the sixteen individual samples of 0900 Ziraat cultivar collected from nurseries of 8 different locations in Turkey. In this analysis the accessions YLV900H, superior cultivar 0900Ziraat from Ataturk Central Horticultural Research Institute of Yalova and A900 (Alara Ltd.) were also included. Monomorphic band patterns were obtained with all the eighteen primer pairs among these samples.

Table 2. Microsatellite (SSR) code, expected and observed number of alleles per locus and allele size-range for the first set of plant material

\begin{tabular}{|c|c|c|c|c|c|}
\hline \multirow[b]{2}{*}{ SSR name } & \multicolumn{3}{|c|}{ Amplification and polymorhism in Prunus species } & \multirow[b]{2}{*}{$\begin{array}{l}\text { No of } \\
\text { alleles } \\
\text { observed }\end{array}$} & \multirow[b]{2}{*}{$\begin{array}{l}\text { Product size } \\
\text { range observed } \\
\text { (bp) }\end{array}$} \\
\hline & $\begin{array}{l}\text { No of } \\
\text { Alleles } \\
\text { expected }\end{array}$ & Product size range expected (bp) & Reference & & \\
\hline \multirow[t]{2}{*}{ PMS2 } & 3 & $140-148$ & Kacar et al. (2005) & 2 & $120,180^{*}$ \\
\hline & 11 & $118-180$ & Demir et al. (2011) & & \\
\hline \multirow[t]{3}{*}{ PMS3 } & 16 & $152-200$ & Cantini et al. (2001) & 3 & $114,152,222 *$ \\
\hline & 10 & $186-218$ & Lacis et al. (2009) & & \\
\hline & 4 & $184-210$ & Kacar et al. (2005) & & \\
\hline PMS40 & 4 & $95-110$ & Cantini et al. 2(001) & 4 & $88,96,100,108$ \\
\hline \multirow[t]{4}{*}{ PS12A02 } & 10 & $160-200$ & $\begin{array}{l}\text { Downey \& Lezzoni } \\
(2000)\end{array}$ & 16 & $\begin{array}{l}122,150,154 \\
182,186,244\end{array}$ \\
\hline & 10 & $181-226$ & Cantini et al. (2001) & & $\begin{array}{l}258,270,290 \\
300,330350\end{array}$ \\
\hline & 4 & $140-190$ & Hormaza (2002) & & $412,426,440,450$ \\
\hline & 20 & $159-165$ & Wuncsh (2009) & & \\
\hline \multirow[t]{3}{*}{ PceGA25 } & 14 & $145-198$ & Cantini et al. (2001) & 5 & $144,170,200,314,364$ \\
\hline & 5 & $158-207$ & Kacar et al. ( 2005) & & \\
\hline & 9 & $154-212$ & Lacis et al. (2009) & & \\
\hline PceGA59 & 10 & $181-226$ & Cantini et al. (2001) & 2 & 176,208 \\
\hline \multirow[t]{2}{*}{ UDP-403 } & 3 & $155-159$ & Cipriani et al. (1999) & 5 & $134,138,146,166,170$ \\
\hline & 5 & $146-154$ & Testolin et al. (2000) & & \\
\hline \multirow[t]{2}{*}{ ВРРСТ34 } & 6 & $224-258$ & $\begin{array}{l}\text { Dirlewanger et al. } \\
(2002)\end{array}$ & 5 & $204,220,240,262,300$ \\
\hline & 7 & $222-260$ & $\begin{array}{l}\text { Holtken \& Gregorius } \\
\text { (2006) }\end{array}$ & & \\
\hline \multirow[t]{2}{*}{ ВРРСТ40 } & 6 & $122-146$ & Dirlewanger et al. (2002) & 9 & $\begin{array}{l}130,134,138 \\
144,152,166\end{array}$ \\
\hline & 5 & $116-142$ & $\begin{array}{l}\text { Holtken \& Gregorius } \\
\text { (2006) }\end{array}$ & & $174,196,202$ \\
\hline
\end{tabular}

*: Not used in cluster analyses 


\subsection{Genetic Diversity of the First Set of the Plant Material}

Nine of the polymorphic SSR primers were used for the first set of plant materials to perform genetic diversity analysis. Based on the 56 polymorphic loci, 54 of them were used to create a dendrogram (Figure 1) which separated the genotypes of the first set into two main clusters. The first cluster consisted of eight genotypes (Lapins, Sweetheart, Ferrovia, Northwunder, Bing, Canada Giant, Yalova905, and Yalova904) mostly included the foreign varieties introduced in Turkey, whereas the second cluster consisted of seven genotypes (Regina, A900, YLV900H, Malatyadalbasti, 0900Ziraat, Kazancioglu and Stella) which included the local cultivars and accessions except Stella and Regina (Figure 1). Among the first cluster members, the highest similarity value of 0.839 was observed between "Bing" and Northwunder and the lowest similarity value of 0.200 was observed between Sweetheart and Yalova905 (Table 3). Similarly in the second cluster, the highest similarity value was determined as 0.973 between 0900Ziraat and Kazancioglu genotypes, and the lowest similarity value of 0.486 in this cluster was shared between Regina and YLV0900H as well as A900. Also in this cluster due to the similarity value of 1.0 between YLV0900H and A900, it was considered that these two sweet cherries were most likely the same genotype (Table 3). The second set of plant materials included 17 individual samples from a registered 0900Ziraat cultivar from nurseries of 8 different locations. Despite of their pomological and morphological differences, all the samples exhibited the same molecular pattern among them and also with YLV0900H, A900, and 0900Ziraat of Agricultural Institute -Yalova indicating the lack of genetic diversity.

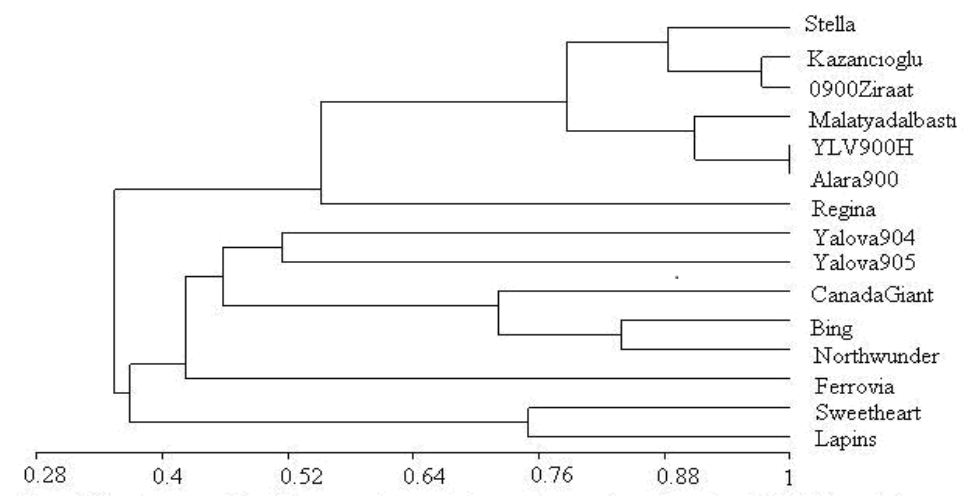

Figure 1. Dendogram of the 15 sweet cherry cultivars and accessions based on UPGMA analysis with nine pairs of microsatellite primers

Table 3 . The similarity matrix of the first set sweet cherry plant material

\begin{tabular}{|c|c|c|c|c|c|c|c|c|c|c|c|c|c|c|c|}
\hline & 言 & 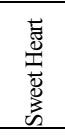 & $\begin{array}{l}\frac{\pi}{5} \\
0 \\
0 \\
0 \\
\end{array}$ & 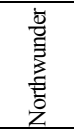 & $\stackrel{\infty}{\oplus}$ & 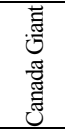 & 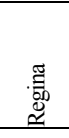 & $\begin{array}{l}8 \\
8 \\
8 \\
\frac{\pi}{0} \\
\end{array}$ & 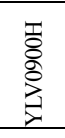 & 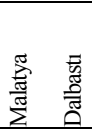 & 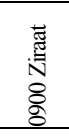 & 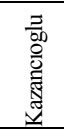 & 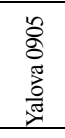 & 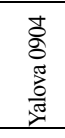 & $\begin{array}{l}\frac{\pi}{\bar{*}} \\
\frac{\pi}{n}\end{array}$ \\
\hline Lanins & 1.000 & & & & & & & & & & & & & & \\
\hline Sweet Heart & 0,750 & 1,000 & & & & & & & & & & & & & \\
\hline Ferrovia & 0,323 & 0,276 & 1,000 & & & & & & & & & & & & \\
\hline Northwunder & 0.467 & 0,357 & 0,444 & 1,000 & & & & & & & & & & & \\
\hline Bing & 0,629 & 0,424 & 0,500 & 0,839 & 1,000 & & & & & & & & & & \\
\hline Canada Giant & 0,313 & 0.467 & 0,345 & 0.714 & 0,727 & 1,000 & & & & & & & & & \\
\hline Regina & 0,242 & 0,258 & 0,533 & 0,345 & 0,412 & 0,323 & 1,000 & & & & & & & & \\
\hline Alara 0900 & 0,316 & 0,500 & 0,229 & 0,235 & 0,308 & 0,444 & 0.486 & 1,000 & & & & & & & \\
\hline YLV0900H & 0,316 & 0,500 & 0,229 & 0,235 & 0,308 & 0,444 & 0.486 & 1,000 & 1,000 & & & & & & \\
\hline Malatya Dalbasti & 0,300 & 0.474 & 0,324 & 0,278 & 0,341 & 0,474 & 0,564 & 0,909 & 0,909 & 1,000 & & & & & \\
\hline 0900 Ziraat & 0,333 & 0,529 & 0,364 & 0,313 & 0,378 & 0,529 & 0,629 & 0,800 & 0,800 & 0,905 & 1,000 & & & & \\
\hline Kazancioglu & 0,286 & 0,485 & 0,313 & 0,258 & 0,333 & 0,485 & 0,588 & 0,769 & 0,769 & 0,878 & 0,973 & 1,000 & & & \\
\hline Yalova 0905 & 0,375 & 0,200 & 0,414 & 0.500 & 0,606 & 0,400 & 0,387 & 0,167 & 0,167 & 0,263 & 0,294 & 0,303 & 1,000 & & \\
\hline Yalova 0904 & 0,378 & 0,229 & 0,412 & 0.424 & 0,474 & 0,343 & 0,278 & 0.488 & 0,488 & 0,558 & 0.410 & 0,421 & 0,514 & 1,000 & \\
\hline Stella & 0.216 & 0.400 & 0.294 & 0.242 & 0.316 & 0.457 & 0.556 & 0.683 & 0.683 & 0.791 & 0.872 & 0.895 & 0.343 & 0.400 & 1.000 \\
\hline
\end{tabular}

\section{Discussion}

In the present study, two sets of plant material covering 31 sweet cherry genotypes were characterized with 23 SSR markers initially developed for peach, sour and sweet cherry. Nine out of 23 primer pairs (BPPCT-034, BPPCT-040, PceGA25, PceGA59, PMS2, PMS3, PMS40, PS12A02, UDP97-403) produced polymorphic bands 
and it was possible to explicitly discriminate the cultivars and accessions studied. These markers have been reported polymorphic in a wider sample of Prunus species (Dirlewanger et al., 2002; Wunsch \& Hormaza 2004) and demonstrated their cross species transferability in previous studies (Cipriani et al., 1999; Downey \& Iezzoni, 2000; Lacis et al., 2009). The PS12A02 was the most informative primer pair used in our study. Similar numbers of putative alleles were previously identified with the same primer pair in sweet cherries (Downey \& Lezzoni, 2000; Kacar et al., 2005). The PMS2, PMS3 and PceGA59 were less informative primer pairs, however these primer pairs were previously reported most informative by Demir et al. (2011). This could be due to the difference in the number of genotypes that were used and also the difference in polyploidy level. When higher number of genotypes (44) were used as in the study of Demir et al. (2011), the PMS2 and PMS3 primer pairs have created 11 and 8 alleles per locus respectively, however produced only 2 and 3 alleles per locus respectively when we used them with 15 genotypes in our study. The sour cherry is a tetraploid species whereas the sweet cherry is diploid. When the PMS2, PMS3 and PceGA59 primer pairs were tested on tetraploid sour cherries by Cantini et al. (2001), they have created the highest number of alleles per locus. Additionally, variation in allele numbers per locus for some primer pairs in sweet cherry genotypes were reported by several studies. For example, the excess amounts of alleles were observed for BPPCT 40 primer pairs in our study when compared to the study of Dirlewanger et al. (2002) and Höltken \& Gregorius (2006). However the PMS2, PMS3 and PceGA25 primer pairs created very low number of alleles in contrast to the observed allele numbers reported in other studies for sweet cherry genotypes (Lacis et al., 2009; Demir et al., 2011) (Table 2). Such discrepancies among different studies in allele numbers for the same primer pairs could also be the result of incorrect fragment size determinations on polyacrylamide gel electrophoresis (SDS-PAGE) method which is known to create ladder-like stutter band patterns (Wünsch \& Hormaza, 2002). When Lacis et al. (2010) compared the PceGA25 and PMS3 primer efficiencies on detection of genetic diversity using both the PAGE and automated capillary electrophoresis methods, they have observed almost twice amounts of alleles for each primer in PAGE method. They have indicated that such putative allelic differences were due to the differences in manual band pattern scoring as well as gel running environmental conditions when PAGE method were applied by various laboratories which might be easily avoided if more sensitive and precise automated capillary electrophesis systems were used (Lacis et al., 2010). A similarity matrix for the 54 polymorphic loci was generated using Nei \& Li coefficient (Nei \& Li, 1979) (Table 3). The dendrogram constructed by UPGMA analysis of the first set of plant material generated two main clusters (Figure 1). The first main cluster consisted of majorly foreign cultivars introduced in Turkey except two accessions Yalova904 and Yalova905. The foreign cultivars in this cluster contains all North American registered types except Ferrovia from Southern Europe (Italy) (Wunsch \& Hormoza, 2002). There were very high genetic diversity among North American cultivars with similarity values ranging from 30 to $70 \%$, although the Turkish accessions Yalova904 and Yalova905 were also grouped together with them. These accessions were more similar (40-60\%) to each other as well as to the southern European originated Ferrovia and the North American originated Bing in the same cluster. Interestingly, despite the fact that Bing is a North American registered cultivar, it was suspected to carry central European germplasm (most probably a seedling of Napoleon) in its pedigree (Wünsch \& Hormaza, 2002). Therefore these results suggest the possibility that Turkish accessions were most probably derived from European germplasm cultivars. Grouping of other Turkish cultivars and accessions in the second main cluster with only two foreign cultivars namely Regina, from Northern Europe and Stella, from north America (the first self compatible commercial cultivar with both American and European germplasm (Lapins, 1971) have further strengthened this possibility. In the second main cluster, the similarity values among the two accessions (YLV0900H and A900) and the two local cultivars (Malatyadalbasti and Kazancioglu) were extremely high, ranging from 77 to $97 \%$. They were also highly similar to "Stella" (68-89\%) and "Regina" (49-59\%). Close genetic as well as morphological similarities among the second main cluster genotypes were also confirmed by other scientists (Kacar et al., 2005; Pedersen, 2006) who suggested that they must have been driven from a very narrow European genetic pool. The accession YLV0900H is a hybrid of Stella x 0900Ziraat (Mahsun Burak personal comm.) which has shown identical allele profiles with A900 and $91 \%$ genetic similarity to Malatyadalbasti and $77 \%$ similarity to Kazancioglu in this study. With the knowledge of this hybrid pedigree we could suggest that the accessions (A0900 and YLV0900H) and the local cultivars (Malatyadalbasti and Kazancioglu) were most probably the clones of each other which were propagated at different locations of Turkey.

\section{Conclusion}

In general, the dendrogram results (Figure 1) reflected that Turkish sweet cherry cultivars were more closely related to each other, thus contained very low genetic variations. Moreover, these cultivars were also observed to be enriched with European and American germplasm. In this study, the second set of plant materials which were collected from eight different locations of Turkey were long considered as different local cultivars and misnamed, due to certain variations in pomological and morphological characteristics among the trees. Thus frequently they 
were referred with different names by growers such as Allahdiyen, Aksehir Napoleon and Salihli cherries (Kacar, 2001; Kacar et al., 2005) emphasizing the locations of their growth area rather than the actual registered cultivar name. Our study using SSR markers have shown no genetic difference among these samples and the original 0900Ziraat cultivar indicating their identity as 0900Ziraat cultivar. In fruit tree propagations, scions are grafted on rootstocks which substantially influence the agricultural features of the grafted tree (Dozier et al., 1984; Jime'nez et al., 2007). The eight different nurseries where the second set of plant samples were collected in our study may have used different rootstocks for 0900Ziraat scions, which may well be the reason of morphological and pomological variations observed in locally adapted trees grown in those nurseries.

\section{Acknowledgements}

This research was supported by a grant from State Planning Organization Grants Program of Turkey (2002K1/ 20610) and Scientific Research Projects Fund of Bogazici University (BAP 320). The authors acknowledge ALARA Agricultural Products Ltd. (Bayramic-Turkey) and Ataturk Central Horticultural Research Institute (Yalova -Turkey) for generously providing plant materials.

\section{References}

Cantini, C., Lezzoni, A. F., Lamboy, W. F., Boritzki, M., \& Struss, D. (2001). DNA fingerprinting of tetraploid cherry germplasm using simple sequence repeats. J. Amer. Soc. Hort. Sci., 126(2), 205-209. http://dx.doi.org/2205-209

Cho, Y. G., Panaud, O., \& McCouch, S. (1996) Cloning and mapping of variety-specific rice genomic DNA sequences: Amplified fragment length polymorphism (AFLP) from silver-stained polyacrylamide gels. Genome, 32, 203-207.

Cipriani, G., Lot, G., Huang, W. G., Marrazzo, M. T., Peterlunger, E., \& Testolin, R. (1999). AC/GT and AG/CT microsatellite repeats in peach [Prunus presica $(\mathrm{L})$ batsch]: isolation, characterisation and cross-species amplification in Prunus. Theor. Appl. Genet., 99, 65-72. http://dx.doi.org/ 10.1007/s001220051209

Demir, T., Demirsoy, L., Demirsoy, H., Kacar, Y.A., Yilmaz, M., \& Macit, I. (2011). Molecular characterization of sweet cherry genetic resources in Giresun, Turkey. Fruits., 66, 53-62. http://dx.doi.org/10.1051/fruits/2010041

Downey, S. L, \& Lezzoni, A. F. (2000). Polymorphic DNA markers in black cherry (Prunus serotina) are identified using sequences from sweet cherry, peach and sour cherry. J. Amer. Soc. Hort. Sci., 125(1), 76-80.

Dozier, W. A., Knowles, J. W., \& Carlton, C. C. (1984). Survival, growth, and yield of peach trees as affected by rootstocks. Hort Science, 19, 26-30.

Doyle, J. J., \& Doyle, J. L. (1987). A rapid DNA isolation procedure for small quantities of fresh leaf tissue. Phytochemical Bulletin, 19(1), 11-15.

Dirlewanger, E., Cosson, P., Tavaud, M., Aranzana, M. J., Poizat, C., Zanetto, A., Arús, P., \& Laigret, F. (2002) Development of microsatellite markers in peach [Prunus persica (L.) Batsch] and their use in genetic diversity analysis in peach and sweet cherry (Prunus avium L.). Theor. Appl. Genet., 105, 127-138. http://dx.doi.org/10.1007/s00122-002-0867-7

Faostat. (2011). Trade, major commodity exporters. http://faostat.fao.org/site/342/default.aspx (2012-10-11).

Guarino, C., Santoro, S., Simolin, L. D., \& Cipriani, G. (2010). Molecular characterisation of ancient Prunus avium L. Germplasm using sweet cherry SSR markers. Journal of Horticultural Science and Biotechnology, 85(4), 295-304.

Heinze, B. (1999). Molecular genetic investigations in wild and cultivated Prunus avium in Austria and beyond. In: Espinel S. And RitterE. (eds), Proceedings of Applications of Biotechnology to Forest Genetics. International Congress Vitoria- Gasteiz, Spain 22-25 1999, pp. 77-80.

Hormaza, J. I. (2002.). Molecular characterization and similarity relationships among apricot (Prunus armeniaca L.) genotypes using simple sequence repeats. Theor. Appl. Genet., 104, 321-328. http://dx.doi.org/10.1007/s001220100684

Höltken, A. M., \& Gregorius, H. R. (2006). Detecting local establishment strategies of wild cherry (Prunus avium L.) BMC Ecology, 6(13). http://dx.doi.org/10.1186/1472-6785-6-13

Jime'nez, S., Pinochet, J., Gogorcena, Y., Betra'n, J., \& Moreno, M. A. (2007). Influence of different vigour cherry rootstocks on leaves and shoots mineral composition. Sci. Hortic., 112, 73-79. http://dx.doi.org/10.1016/j.scienta.2006.12.010 
Kaçar, Y. A. (2001). Classification of important sweet cherry (Prunus avium L.) and sour cherry (Prunus cerasus L.) cultivars and typesgrowing in turkey by DNA fingerprinting methods, Çukurova Univ., thesis, Adana, Turkey, p. 190.

Kaçar, Y. A., Iezzoni, A. F., \& Çetiner, M. S. (2005). Sweet cherry cultivar identification by using SSR markers. $J$. Biol. Sci., 5, 616-619. http://dx.doi.org/ 10.3923/jbs.2005.616.619

Kaska, N., Paydas, S., \& Caglar, S. (1998). Preparation of Turkish sweet cherries for European markets. Acta. Hortic., 46, 713-717.

Lacis, G., Isaak, R., Silvija, R., Vikto, T., \& Lezzoni, A. F. (2009). Assessment of genetic diversity of Latvian and Swedish sweet cherry (Prunus avium L.) genetic resources collections by using SSR (microsatellite) markers. Sci. Hortic., 121, 451-457. http://dx.doi.org/10.1016/j.scienta.2009.03.016

Lacis, G., Rashal, I., \& Trajkovski, V. (2010). Comparative analysis of sweet cherry (P. avium) genetic diversity revealed by two methods of SSR marker detection. Proceedings of the Latvian Academy of Sciences. Section B, 64, 149-158. http://dx.doi.org/ 10.2478/v10046-010-0024-7

Lapins, K. O. (1971). Stella, a self-fruitful sweet cherry. Can. J. Plant Sci., 51, 252-252.

Iezzoni, A, Schmidt, H., \& Albertini, A. (1990). Cherries (Prunus spp.), p. 110-173. In J.N.Moore and J.R. Ballington (eds.). Genetic resources of temperate fruit and nut crops. Intl. Soc. Hort. Sci., Wageningen, The Netherlands.

Mohanty, A., Martin, J. P., \& Aguinagalde, I. (2001). Chloroplast DNA study in wild populations and some cultivars of Prunus avium L. Theor. Appl. Genet., 103, 112-117. http://dx.doi.org/ 10.1007/s001220000532

Nei, M., \& Li, W. H. (1979). Mathematical model for studying genetic variation in terms of restriction endonucleases. Proc. Natl. Acad. Sci., 76, 5269-5273. http://dx.doi.org/10 5269-5273

Pedersen, B. H. (2006). DNA fingerprints of 51 sweet and sour Prunus accessions using simple sequence repeats. J Hortic Sci Biotech, 81, 118-124.

Sosinski, B., Gannavarapu, M., Hager, L. D., Beck, L. E., King, G. J., Ryder, C. D., Rajapakse, S., Baird, W. V., Ballard, R. E., \& Abbot, T. A. (2000). Characterization of microsatellite markers in peach (Prunus persica L.). Theor. Appl. Genet., 97, 1034-1041. http://dx.doi.org/ 10.1007/s001220051499

Struss, D., Boritzki, M., Glozer, K., \& Southwick, S. M. (2001). Detection of genetic diversity among populations of sweet cherry. Journal of Horticultural Science \& Biotechnology, 76(3), 362-367.

Testolin, R., Marrazzo, T., Cipriani, G., Quarta, R., Verde, I., Dettori, M. T., Pancaldi, M., \& Sansavini, S. (2000). Microsatellite DNA in peach [Prunus persica (L.) Batsch] and its use in fingerprinting and testing the genetic origin of cultivars. Genome, 43, 512-520. http://dx.doi.org/10.1007/s00122-002-1128-5

Turkec, A., Sayar, M., \& Heinze, B. (2006). Identification of sweet cherry cultivars (Prunus avium L.) and analysis of their genetic relationships by chloroplast sequence characterised amplified regions (cpSCAR). Genetic Resources and Crop Evolution, 53, 1635-1641. http://dx.doi.org/ 10.1007/s10722-005-2285-6

Turkoglu, Z., Bilgener, S., Ercisli, S., Bakir, M., Koc, A., Akbulut, M., Gercekcioglu, R., Gunes, M., \& Esitken, A. (2010). Simple sequence repeat-based assessment of genetic relationships among Prunus rootstocks. Genetic and Molecular Research, 9(4), 2156-2165. http://dx.doi.org/10.4238/vol9-4gmr957

Wunsch, A., \& Hormaza, J. I. (2002) Molecular characterisatiom of sweet cherry (prunus avium L.) genotypes using peach [ Prunus persica (L.) Batsch ] SSR sequences. Heredity, 89, 56-63. http://dx.doi.org/10.1038/sj.hdy.6800101

Wunsch, A., \& Hormaza, J. I. (2004). Molecular evaluation of genetic diversity and Sallele composition of local Spanish sweet cherry (Prunus avium L.) cultivars. Genet. Resour. Crop Evol., 51, 635-641. http://dx.doi.org/10.1023/B:GRES.0000024649.06681.43

Wunsch, A. (2009). Cross-transferable polymorphic SSR loci in Prunus species. Sci. Hortic., 120, 348-352. http://dx.doi.org/10.1016/j.scienta.2008.11.012

Zarrouk, O., Gogorcena, Y., Go'mez-Aparisi, J., Betra'n, J. A., \& Moreno, M. A. (2005). Influence of peach and almond hybrids rootstocks on flower and leaf mineral concentration, yield and vigour of two peach cultivars. Sci. Hortic., 106, 502-514. http://dx.doi.org/10.1016/j.scienta.2005.04.011

Zohary, D., \& Hopf, M. (2000). Domestication of plants in the old world. 3rd edn. Oxford University Press, New York, pp. 182. http://dx.doi.org/10.1007/s006060300003 